\title{
Computer Aided Screening of Indirubin Analogues Targeting GSK-3 $\beta$ Protein Using Molecular Docking
}

\author{
Luu Van Huyen", Tran Quoc Toan², Pham Quoc Long'² and Pham Minh Quan ${ }^{2,3 *}$ \\ ${ }^{1}$ Hanoi University of Natural Resources and Environment, Vietnam \\ ${ }^{2}$ Institute of Natural Products Chemistry, Vietnam Academy of Science and Technology, Vietnam \\ ${ }^{3}$ Graduate University of Science and Technology, Vietnam Academy of Science and Technology, Vietnam
}

*Corresponding author: Pham Minh Quan, Institute of Natural Products Chemistry, Vietnam Academy of Science and Technology,

Vietnam

\section{ARTICLE INFO}

Received: 幽 July 24, 2019

Published: 蔧 July 31, 2019

Citation: Luu Van Huyen, Tran Quoc T, Pham Quoc L, Pham Minh Q. Computer Aided Screening of Indirubin Analogues Targeting GSK-3 $\beta$ Protein Using Molecular Docking. Biomed J Sci \& Tech Res 20(2)-2019. BJSTR. MS.ID.003414.

Keywords: Indirubin Derivatives; Docking; GSK-3 $\beta$, Anti-Cancer

Abbreviations: PDB ID: Protein Data Bank; ADT: Auto Dock Tools; NSCLC: Non-Small-Cell Lung Cancer; SCLC: Small Cell Lung Cancer

\section{ABSTRACT}

Objective: To study the inhibition effects of indirubin analogues with GSK-3 $\beta$ protein using molecular modeling and docking tools.

Materials and Methods: Crystal structure of GSK- $3 \beta$ was taken from Protein data bank (PDB ID: 1Q41). The construction and optimization of the three-dimensional structure of small molecules was done using ChemDraw and Chem3D version 18.1 (PerkinElmer®). All ligands and protein were prepared for docking using Auto Dock Tools (ADT) 1.5.6. AutoDock 4.2.6 was utilized for the molecular docking simulation.

Results: Overall, amongst 12 indirubin derivatives, 8 analogues appear to inhibit GSK-3 $\beta$ function based on docking score ranking, the formed hydrogen bonds of topmost compounds share same residues in the binding site as compared to standard indirubin3'-oxime.

Conclusion: Further in vitro and in vivo experimentation are needed to confirm the efficacy and potency of potential compounds. This model can be applied for design candidate drug with desired biological properties by chemical modification in functional group at appropriate places.

\section{Introduction}

Lung cancer is one of the leading causes of cancer-related death worldwide both with men and women, it is responsible for about 1.3 million deaths annually [1,2]. In Vietnam, lung cancer has very high rate of mortality with 24,000 new cases annually in which $90 \%$ result in deaths. There are two major types of lung cancer: non-small-cell lung cancer (NSCLC) and small cell lung cancer (SCLC) [3,4]. Non-small cell lung cancer accounts for about $80 \%$ of overall lung cancer cases. Despite many efforts have been made in the last 25 years, the treatment drugs for patients remain poor efficacy. Indirubin and its analogues have been well known for their activities against many types of cancer cell line, mainly by inhibition of cell proliferation and induction of cell death $[5,6]$. These data suggest the development of indirubin derivatives as potential candidates for the treatment of lung cancer. Recent studies have discovered activity of GSK-3 $\beta$ in cancer and its role in regulating tumor cell profileration and survival of multiple human malignances. For the purpose of finding novel compounds and new idea for drug design, 12 analogues of indirubin were allowed to dock with GSK-3 $\beta$ protein.

\section{Materials and Methods}

Crystal structure of GSK-3 $\beta$ was taken from Protein data bank (PDB ID: 1Q41). The construction and optimization of the threedimensional structure of small molecules was done using Chem Draw and Chem3D version 18.1 (PerkinElmer®). All ligands and protein were prepared for docking using Auto Dock Tools (ADT) 1.5.6. The ligands and protein were protonated. The default Kollman charges and solvation parameters were allocated to the protein atoms. Gasteiger charges were added to each ligand atom. Grid box was generated around possible ligand-binding site. The precalculated binding affinity of each ligand's atom type was prepared using Autogrid. Auto Dock 4.2.6 was utilized for the molecular docking simulation and Accelrys Discovery Studio Visualizer 4.0 was used for docking results visualization (Figure 1) and (Table 1). 


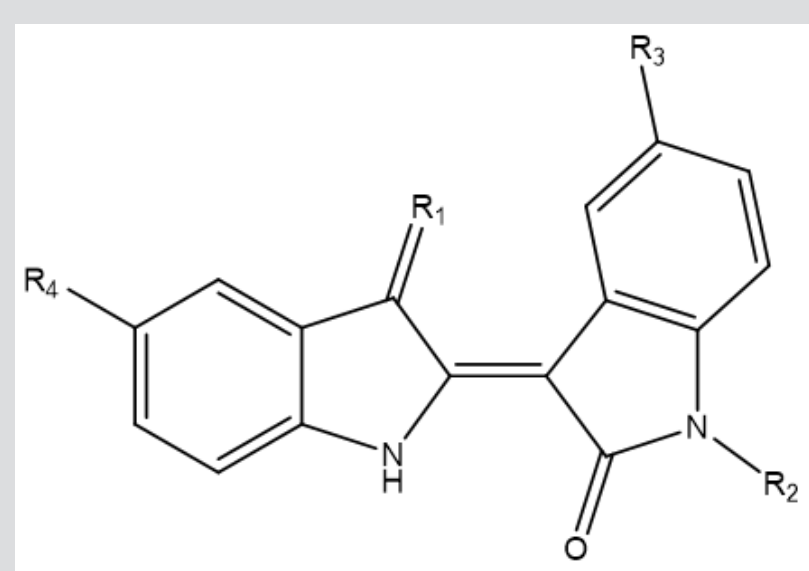

Figure 1.

Table 1.

\begin{tabular}{|c|c|c|c|c|}
\hline No & R1 & R2 & R3 & R4 \\
\hline 1 & $\mathrm{O}$ & $\mathrm{H}$ & $\mathrm{NH}_{2}$ & $\mathrm{H}$ \\
\hline 2 & $\mathrm{O}$ & $\mathrm{H}$ & $\mathrm{NH}_{2}$ & $\mathrm{Br}$ \\
\hline 3 & $\mathrm{O}$ & $\mathrm{H}$ & $\mathrm{NHAc}$ & $\mathrm{H}$ \\
\hline 4 & $\mathrm{O}$ & $\mathrm{H}$ & $\mathrm{NHAc}^{2}$ & $\mathrm{Br}$ \\
\hline 5 & $\mathrm{NOH}$ & $\mathrm{H}$ & $\mathrm{NH}^{2}$ & $\mathrm{H}$ \\
\hline 6 & $\mathrm{NOH}$ & $\mathrm{H}$ & $\mathrm{NH}^{2}$ & $\mathrm{Br}$ \\
\hline 7 & $\mathrm{NOH}$ & $\mathrm{H}$ & $\mathrm{NHAc}^{2}$ & $\mathrm{H}$ \\
\hline 8 & $\mathrm{NOH}$ & $\mathrm{H}$ & $\mathrm{NHAc}^{2}$ & $\mathrm{Br}$ \\
\hline 9 & $\mathrm{NOH}$ & $\mathrm{H}$ & $\mathrm{NO}^{2}$ & $\mathrm{Br}$ \\
\hline 10 & $\mathrm{NOH}$ & $\mathrm{CH}$ & $\mathrm{NO}^{2}$ & $\mathrm{H}$ \\
\hline 11 & $\mathrm{NOH}$ & $\mathrm{H}$ & $\mathrm{NO}^{2}$ & $\mathrm{H}$ \\
\hline 12 & $\mathrm{NOH}$ & $\mathrm{CH}$ & $\mathrm{NO}^{2}$ & $\mathrm{Br}$ \\
\hline
\end{tabular}

\section{Results}

In general, 8 derivatives of indirubin showed better docking score to GSK-3 $\beta$ than the standard indirubin-3'-oxime. Most of the designed derivatives form $\mathrm{H}$-bonds with GSK- $3 \beta$ when binding in its ATP-binding site. The hydrogen bonds occur mainly with VAL135 and ASP133 in the Hinge region and ARG14 which is the important region for the function of protein. In some of the molecules it also forms H-bonds with GLN185, LEU132, ASP200 and LYS88 amino acids of GSK-3 $\beta$ (Table 2).

\section{ISSN: 2574-1241}

DOI: 10.26717/BJSTR.2019.20.003414

Pham Minh Quan. Biomed J Sci \& Tech Res

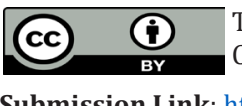

This work is licensed under Creative Commons Attribution 4.0 License

Submission Link: https://biomedres.us/submit-manuscript.php
Table 2.

\begin{tabular}{|c|c|c|c|}
\hline No. & $\begin{array}{c}\text { Docking score } \\
\text { (kcal/mol) }\end{array}$ & No. & $\begin{array}{c}\text { Docking Score } \\
\text { (kcal/mol) }\end{array}$ \\
\hline Compound 1 & -8.5300 & Compound 8 & -9.7500 \\
\hline Compound 2 & -8.2500 & Compound 9 & -12.0100 \\
\hline Compound 3 & -7.7200 & Compound 10 & -11.9500 \\
\hline Compound 4 & -7.5600 & Compound 11 & -11.4300 \\
\hline Compound 5 & -11.2400 & Compound 12 & -11.6500 \\
\hline Compound 6 & -11.0700 & Indirubin-3'- & -9.5900 \\
\hline Compound 7 & -9.9800 & & \\
\hline
\end{tabular}

\section{Conclusion}

Molecular docking studies were conducted for all the designed molecules against the structure of protein GSK-3 $\beta$. There 8 amongst 12 compounds exhibit potential inhibition activity in the ATP-binding site of the protein. Further in vitro and in vivo experimentation are needed to confirm the efficacy and potency of potential compounds and could be leads compounds for medicine drugs.

\section{References}

1. Fossella F, Pereira JR, von Pawel J, Pluzanska A, Gorbounova V, et al. (2003) Randomized, multinational, phase III study of docetaxel plus platinum combinations versus vinorelbine plus cisplatin for advanced non-small-cell lung cancer: the TAX 326 study group. J Clin Oncol 21(16): 3016-3024.

2. Biesalski HK, Bueno de Mesquita B, Chesson A, Chytil F, Grimble R, et al. (1998) European Consensus Statement on Lung Cancer: risk factors and prevention. Lung Cancer Panel. CA Cancer J Clin 48(3): 167-176.

3. Shen YC, Chou CJ, Chiou WF, Chen CF (2001) Anti-inflammatory effects of the partially purified extract of radix Stephaniae tetrandrae: comparative studies of its active principles tetrandrine and fangchinoline on human polymorphonuclear leukocyte functions. Mol Pharmacol 60(5): 10831090.

4. Choi HS, Kim HS, Min KR, Kim Y, Lim HK, et al. (2000) Anti-inflammatory effects of fangchinoline and tetrandrine. J Ethnopharmacol 69(2): 173179.

5. Eisenbrand G, Hippe F, Jakobs S, Muehlbeyer S (2004) Molecular mechanisms of indirubin and its derivatives: novel anticancer molecules with their origin in traditional Chinese phytomedicine. Journal of Cancer Research and Clinical Oncology 130(11): 627-635.

6. Karapetyan G, Chakrabarty K, Hein M, Langer P (2011) Synthesis and bioactivity of carbohydrate derivatives of indigo, its isomers and heteroanalogues. Chem Med Chem 6(1): 25-37.

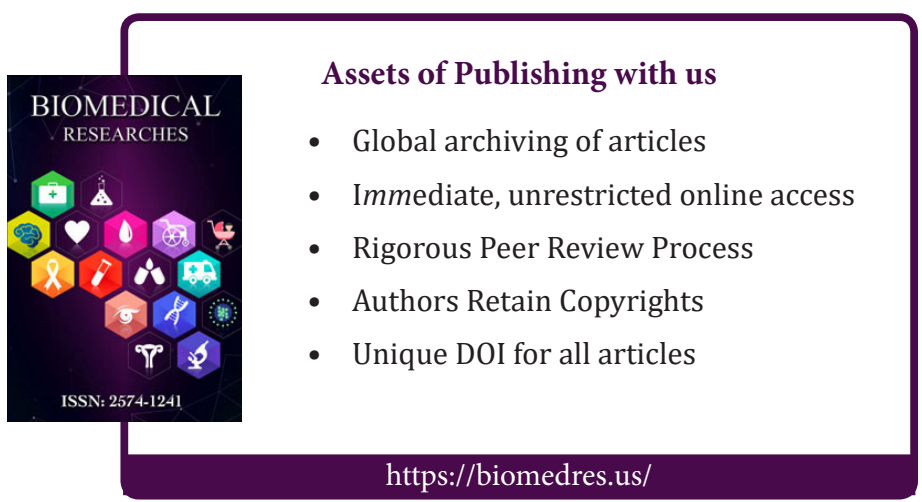

